those in the water-holding capacity. Since changing the particle size greatly alters the water-holding capacity but does not alter the fibre or lignin content it seems that particle size is more important than fibre or lignin content.

The coarse-bran preparation was closer to pure bran, which is the material left after the flour has been separated from the grain. The fine-bran appeared to containan appreciable amount of what seemed to be flour (endosperm). The difference between the two preparations is a reflection of the degree of milling or the stage of extraction at which the brans were obtained.

In the treatment by bran of diverticular disease and constipation it seems that a useful criterion for success is the amount of alteration of the stool weight (Burkitt et al., 1972). Theoretically increasing the stool weight should be achieved by increasing the dietary intake of fibre from any plant source, from vegetables and fruits as well as bran, so long as there is a substantial waterholding capacity as has been shown, for example, in carrots, apples, oranges, brussels sprouts, etc. (McConnell et al., 1974). While the water-holding capacity of bran is in comparison a modest one the fact that it is $85 \%$ dry material magnifies its importance. It is easier for most people to take $20 \mathrm{~g}$ of bran as a source of fibre than the comparable amount of fibre from other sources (200-300g raw material).

It is possible that if fine bran were given in a larger dose there would be sufficient large particles and water-holding capacity for it to improve bowel function also. This form of bran, however, contains considerable amounts of absorbable carbohydrate (two of our female patients complained of having put on $4 \mathrm{lb}$ and $5 \mathrm{lb}$ in weight over four weeks) and increasing the dose might result in unacceptable weight gain.

This work was done during the tenure of Scottish Endowments Ho:pitals Research Trust Grant No. 418 and with support from the British Nutrition Foundation.

We thank Miss E. G. P. Drummond for skilled technical help and Dr. J. B. Hutchinson, Flour Milling and Baking Research Association, Chorleywood, for advice and help.

Requests for reprints should be sent to A.N.S.

\section{References}

Arfwidsson, S., and Kock, N. G. (1964). Acta Chirurgica Scandinavica, Suppl. No. 342, p. 1

Burkitt, D. P., Walker, A. R. P., and Painter, N. S. (1972). Lancet, 2, 1408 Findlay, J. M., et al. (1974). Lancet, 1, 146.

Harvey, R. F., Pomare E. W. and Heaton, K. W. (1973). Lancet, 1278. Helfferich, F.' (1962). Ion Exchange, p. 92. New York, McGraw-Hill.

Helferich, . (1962). Ion Exchange, p. 92. New A. C. (1969). Gut, 10, 842. Kirwan, W. O., and Smith, A. N. (1974). Scandinavian fournal of Gastroenterology. In press.

McConnell, A. A., Eastwood, M. A., and Mitchell, W. D. (1974). Fournal of the Science of Food and Agriculture. In press.

Painter, N. S., Almeida, A. Z., and Colebourne, K. W. (1972). British Medical fournal, 2, 137.

Painter, N. S., and Truelove, S. C. (1964). Gut, 5, 201.

Smith, A. N., Giannakos, V., and Clarke, S. (1971). Fournal of the Royal College of Surgeons, Edinburgh, 16, 276.

van Soest, P. J. (1963). Fournal of the Association of Official Agricultural Chemists, 46, 829.

\title{
Lack of Harmful Effect of Oats on Small-intestinal Mucosa in Coeliac Disease
}

\author{
A. S. DISSANAYAKE, S. C. TRUELOVE, R. WHITEHEAD
}

British Medical fournal, 1974, 4, 189-191

\section{Summary}

It is well established that wheat, rye, and barley are harmful to patients with coeliac disease, but the effect of oats remains in doubt. Four patients with coeliac disease, who had shown complete mucosal recovery after prolonged treatment with a strict gluten-free diet, volunteered to consume oats in addition to their gluten-free diet for a period of one month and were studied by jejunal biopsy before and after the experimental period. The patients remained entirely symptom-free and, more important, the jejunal mucosa was undamaged as judged by appearances under dissecting and light microscopes, quantitative histological studies, and disaccharidase content. It is concluded that oats are harmless to coeliac subjects and can be included in a gluten-free diet.

\section{Introduction}

It is well established that wheat, rye, and barley are damaging to the small-intestinal mucosa of coeliac subjects, while

Nuffield Department of Clinical Medicine, and Department of Morbid Anatomy, Radclifie Infirmary, Oxford

A. S. DISSANAYAKE, M.B., D.PHIL., Research Assistant S. C. TRUELOVE, M.D., F.R.C.P., Physician

R. WHITEHEAD, M.D., M.R.C.PATH., Consultant Pathologist maize and rice are harmless. The effect of oats remains controversial (Anderson et al., 1972).

We felt, therefore, that a study of the histological responses and disaccharidase levels in jejunal biopsy specimens from coeliac patients who had responded well to a gluten-free diet and who were then fed on oats would solve the problem.

\section{Patients and Methods}

Four patients volunteered to take part in this study. In all cases their coeliac disease had been diagnosed on the basis of their clinical presentation and the finding of a flat mucosa on jejunal biopsy together with severe depression of all three disaccharidases. They rapidly became symptom free on a strict gluten-free diet and the diagnosis was confirmed by a repeat jejunal biopsy after several months which showed that the morphological appearances and disaccharidases had become normal. At the time of entry into this study all four patients had been on a strict gluten-free diet for at least one year.

These patients were assessed clinically and had routine blood investigations and a jejunal biopsy at the start of the study. They were given porridge oats to be taken $40-60 \mathrm{~g} /$ day as porridge, oat cakes, or "flap-jacks" and also instructed to continue on an otherwise strict gluten-free diet. This dose of oats was selected because it was felt that larger daily doses are not easily tolerated by many normal people. Furthermore, from our recent follow-up study of coeliac patients it is clear that even small amounts of wheat gluten produce pronounced 
abnormalities in the jejunal mucosa and depression of the disaccharidases (Dissanayake et al., 1974). The patients were reassessed at the end of four weeks and all the investigations, including a jejunal biopsy, were repeated. Quantitative histological studies were performed on the biopsy specimens, their disaccharidase content was estimated, and they were examined by dissecting and light microscopy. The quantitative histological studies were performed by the method of Dunnill and Whitehead (1972) and we relied chiefly upon the surface: volume ratio. The disaccharidase estimations were performed by the method described by Pena et al. (1972).

One of the patients (case 3 ) was one of a pair of identical twins, both of whom had coeliac disease, and her twin sister (case 1) had the same tests, including jejunal biopsies on the same days, but did not consume oats. Since they both lived with their parents and worked in the same office their diets were virtually identical apart from the oats.

\section{Results}

All four patients remained symptom free throughout the period of study and there was no appreciable change in the erythrocyte sedimentation rate or in the serum levels of iron, vitamin $B_{12}$, or folate. The serum IgA and IgM fell below the normal range in the case of one patient (case 4) after oats, but random fluctuations in serum immunoglobulins are not unusual in patients on a strict gluten-free diet (Dissanayake et al., 1974). The appearances on dissecting and light microscopy remained unchanged (fig.). The results of the quantitative histological studies are shown in table $I$ and the values for the biopsy specimen at the time of diagnosis are given for comparison. Whereas the increase in ratio for the biopsy specimen after a gluten-free diet was highly significant compared to the pretreatment ratio there was no difference between that before oats and that after oats.

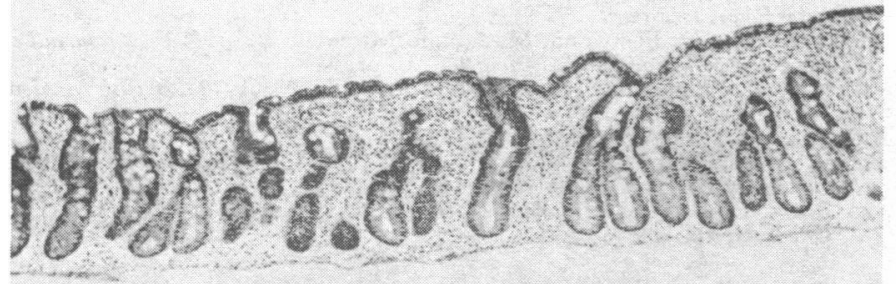

A
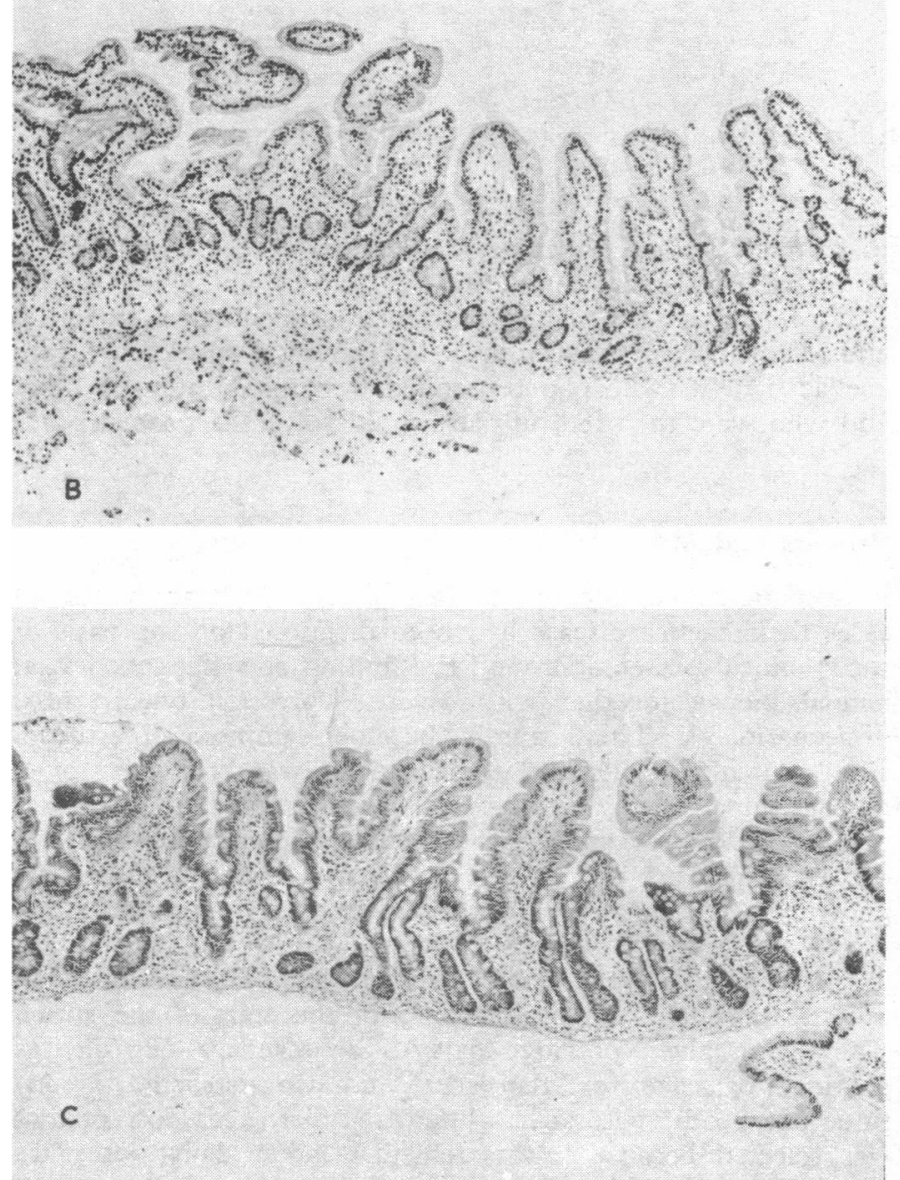
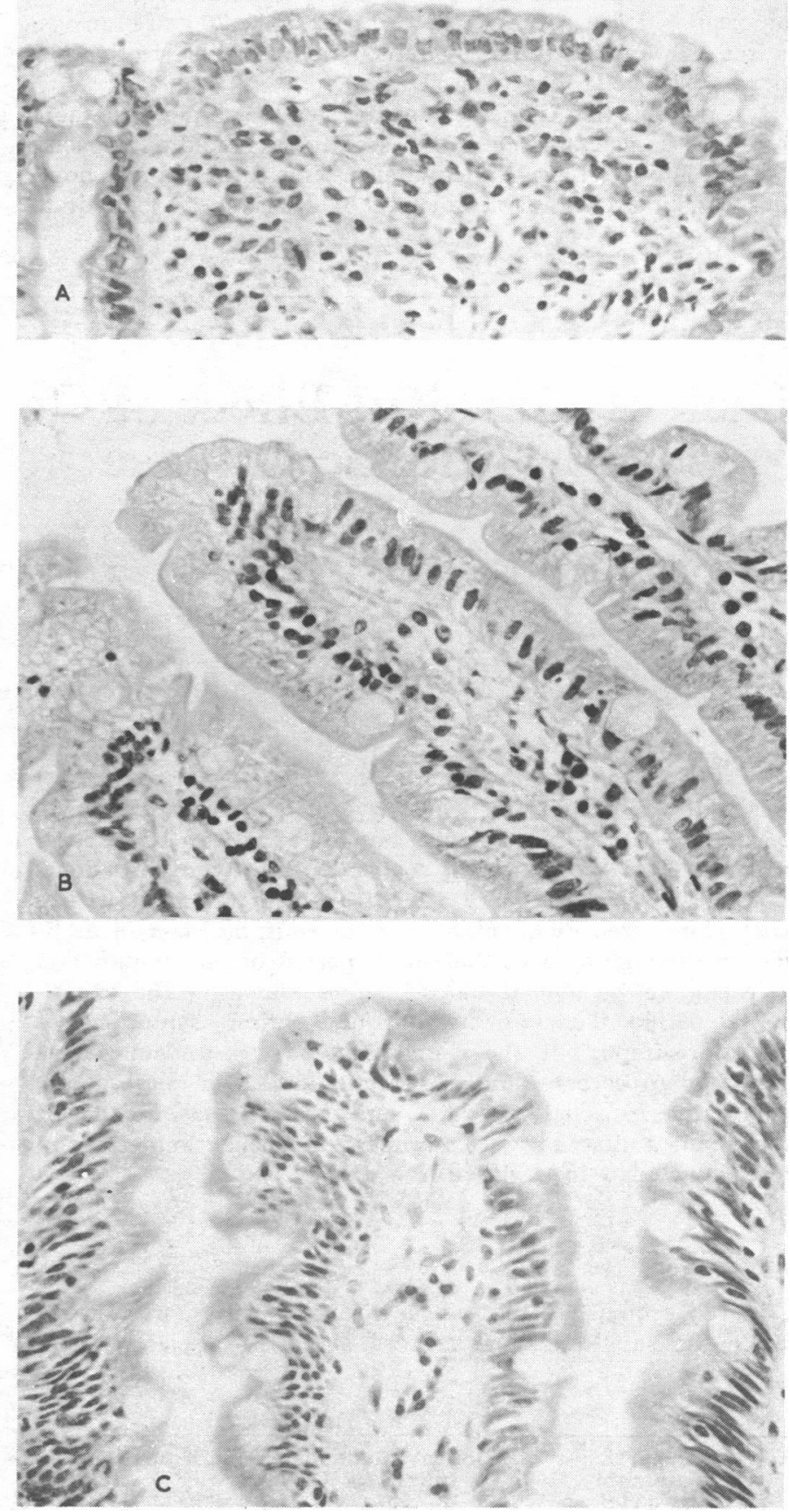

FIG. 1-Low power (left) and high power (right) jejunal biopsy appearances in case 2 (A) at time of diagnosis, (B) after one year on gluten-free diet, (C) after one month of consuming oats. 
The levels of lactase, sucrase, and maltase at the time of diagnosis, before starting oats, and after oats are shown in table II. The changes in enzyme levels before and after oats were not consistent and none of the values fell below the lower limit of normal. These changes did not reach levels of statistical significance as judged by Student's paired $t$ test.

TABLE I-Surface:Volume Ratio of Fejunal Biopsy Specimens before and after consuming Oats with Otherwise Strict Gluten-free Diet. Values at time of diagnosis are given for comparison

\begin{tabular}{|c|c|c|c|}
\hline \multirow{2}{*}{ Case No. } & \multicolumn{3}{|c|}{ Surface:Volume Ratio } \\
\hline & At Diagnosis & $\begin{array}{l}\text { Before Starting } \\
\text { Oats }\end{array}$ & $\begin{array}{l}\text { After } 1 \text { Month } \\
\text { on Oats }\end{array}$ \\
\hline $\begin{array}{c}1 \\
\text { (Control)* }\end{array}$ & $11 \cdot 1$ & $43 \cdot 0$ & $56 \cdot 1$ \\
\hline $\begin{array}{l}2 \\
3 \\
4 \\
5 \\
\end{array}$ & $\begin{array}{r}11.5 \\
7.5 \\
9.9 \\
9.4 \\
\end{array}$ & $\begin{array}{l}49.0 \\
53.4 \\
33.8 \\
45.5\end{array}$ & $\begin{array}{l}40 \cdot 4 \\
47 \cdot 2 \\
36 \cdot 9 \\
43 \cdot 3\end{array}$ \\
\hline $\begin{array}{l}\text { Mean } \\
\text { S.D. } \\
\text { S.E. }\end{array}$ & $\begin{array}{l}9.58 \\
1.64 \\
0.82\end{array}$ & $\begin{array}{r}45.43 \\
8.40 \\
4.20\end{array}$ & $\begin{array}{r}41 \cdot 95 \\
4 \cdot 38 \\
2 \cdot 18\end{array}$ \\
\hline Paired $t$ test & \multicolumn{3}{|c|}{$\begin{array}{l}t=7.9084 \\
\mathrm{P}<0.01\end{array}$} \\
\hline
\end{tabular}

* Twin sister of case 3. She did not consume oats but acted as control for her sister and her results are not included in statistical analysis.

When serial biopsy is performed random fluctuations in enzyme content are not unusual and this was well illustrated by the findings in the control patient (case 1) who remained on a strict gluten-free diet.

\section{Discussion}

Oat flour contains less protein than wheat flour according to Fletcher and MoCririck (1958). The prolamin content of oat protein is probably $10 \%$ of the total protein compared to $40 \%-50 \%$ in the case of wheat protein (Brohult and Sandegren, 1954). van de Kamer et al. (1970) believe that the harmful effect of any cereal protein on the coeliac mucosa is determind by the glutamine content of the protein, which can be expressed as a ratio of the amide nitrogen to amino nitrogen. Based on their previous feeding studies with common food cereals Dicke et al. (1953) considered that any value greater than 12 for this ratio represented toxicity. Oats, with a ratio of 13 , fall into the lower toxic levels.

Ewart (1966) was unable to show any lines of antigenic identity when comparing oats with wheat using a double diffusion technique with a rabbit antigliadin antiserum. He found a definite relationship, however, between rye and wheat and a partial similarity between barley and wheat flour. Thus, from the scanty knowledge of its chemical composition and antigenicity, oat protein does not seem to resemble wheat protein closely.

The gluten content of oats has not been clearly shown but if this were related to the amide nitrogen: amino nitrogen ratio it would be about half that of wheat (van de Kamer et al. 1970). Therefore $60 \mathrm{~g}$ of oats would be equivalent to about 3-5 $\mathrm{g}$ of gluten. In our follow-up study of coeliac patients the harmful effect of much smaller doses of gluten than this has been clearly shown. The present study therefore shows that oat flour is not harmful to the jejunal mucosa of patients with coeliac disease.

\section{References}

Anderson, C. M., Gracey, M., and Burke, V. (1972). Archives of Disease in Childhood, 47, 292.

Brohult, S., and Sandegren, E. (1954). In The Proteins, ed. H. Neurath and K. Bailey, vol. 2, part A, p. 487. New York, Academic Press.

Dicke, W. K., Weijers, H. A., and Van de Kamer, J. H. (1953). Acta Paediatrica, 42, 34

Dissanayake, A. S., Truelove, S. C., and Whitehead, R. (1974). Quarterly Fournal of Medicine, 43, 161.

Dunnill, M. S., and Whitehead, R. (1972). Fournal of Clinical Pathology, 25, 243.

Ewart, J. A. D. (1966). Fournal of the Science of Food and Agriculture, 17, 279. Fletcher, R. F., and McCririck, M. Y. (1958). British Medical fournal, 2, 299. van de Kamer, J. H., Weijers, H. A., and Wauters, E. A. K. (1970). In Coeliac Disease, ed. C. C. Booth and R. H. Dowling, p. 106. Edinburgh, Churchill Livingstone.

Pena, A. S., Truelove, S. C., and Whitehead, R. (1972).Quarterly fournal of Medicine, 41, 457.

TABLE II-Disaccharideas Levels in Fejunal Biopsy Specimens in Patients with Coeliac Disease before and after Oats

\begin{tabular}{|c|c|c|c|c|c|c|c|c|c|c|c|}
\hline \multirow{2}{*}{\multicolumn{3}{|c|}{$\begin{array}{l}\text { Case } \\
\text { No. }\end{array}$}} & \multicolumn{3}{|c|}{ Lactase (U/g wet wt) } & \multicolumn{3}{|c|}{ Sucrase (U/g wet wt) } & \multicolumn{3}{|c|}{ Maltase (U/g wet wt) } \\
\hline & & & Untreated & Before Oats $\dagger$ & After Oats & Untreated & Before Oats $†$ & After Oats & Untreated & Before Oats $†$ & After Oats \\
\hline 1 (Con & ol)* & .. & 0.2 & 2.6 & $4 \cdot 2$ & 0.3 & 8.9 & $9 \cdot 2$ & 2.8 & $37 \cdot 2$ & $29 \cdot 4$ \\
\hline $\begin{array}{ll}2 & \\
3 & \cdots \\
4 & \cdots \\
5 & \cdots \\
\end{array}$ & $\begin{array}{l}. . \\
\because . \\
\because .\end{array}$ & $\begin{array}{l}. . \\
\because . \\
\cdots\end{array}$ & $\begin{array}{l}0.0 \\
0.0 \\
0.0 \\
0.0\end{array}$ & $\begin{array}{l}2.5 \\
2.2 \\
1.9 \\
1.8\end{array}$ & $\begin{array}{l}2.1 \\
1.7 \\
1.9 \\
1.5\end{array}$ & $\begin{array}{l}0 \\
0.6 \\
0.8 \\
0.3\end{array}$ & $\begin{array}{r}7.2 \\
11.1 \\
6.6 \\
11.8\end{array}$ & $\begin{array}{r}7.5 \\
10.5 \\
3.6 \\
6.1\end{array}$ & $\begin{array}{l}2.2 \\
3.0 \\
2.2 \\
0.6\end{array}$ & $\begin{array}{l}25.8 \\
19.1 \\
18.9 \\
31.8\end{array}$ & $\begin{array}{l}23 \cdot 1 \\
33 \cdot 2 \\
13 \cdot 1 \\
25 \cdot 3\end{array}$ \\
\hline $\begin{array}{l}\text { Mean } \\
\text { S.D. } \\
\text { S.E. }\end{array}$ & $\because \ddot{ }$ & $\because$. & $\begin{array}{l}0.0 \\
0.0 \\
0.0\end{array}$ & $\begin{array}{l}2.10 \\
0.32 \\
0.16\end{array}$ & $\begin{array}{l}1.80 \\
0.25 \\
0.13\end{array}$ & $\begin{array}{l}0.43 \\
0.35 \\
0.17\end{array}$ & $\begin{array}{l}9.18 \\
2.65 \\
1.33\end{array}$ & $\begin{array}{l}6.93 \\
2.88 \\
1.44\end{array}$ & $\begin{array}{l}2.00 \\
1.00 \\
0.50 \\
\end{array}$ & $\begin{array}{r}23.90 \\
6 \cdot 17 \\
3.08\end{array}$ & $\begin{array}{r}23.6 \\
8 \cdot 2 \\
4 \cdot 1\end{array}$ \\
\hline \multicolumn{3}{|c|}{ Paired $t$ test } & \multicolumn{3}{|c|}{ 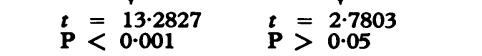 } & \multicolumn{3}{|c|}{$\begin{array}{l}t=6.5026 \\
\mathrm{P}\end{array}$} & \multicolumn{3}{|c|}{$\begin{array}{ll}t=6.1930 & t \\
\mathrm{P} & =0.01\end{array}$} \\
\hline
\end{tabular}

* Twin sister of Case 3. She did not consume oats but acted as control for her sister, and her results are not included in statistical analysis.

†Patients were on gluten-free diet. 